\title{
ELECTRA E ORESTES: OS EFEBOS EURIPIDIANOS NA KHÓRA DE ARGOS
}

\begin{abstract}
Márcia Cristina Lacerda Ribeiro*
RESUMO: Este artigo pretende analisar a Electra de Eurípides, sob um ângulo específico - o exame da efebia (ephēbeía). O drama de exclusãoinclusão de Electra e Orestes, somado ao espaço de ação, a fronteira, levou-nos a conjecturar que os jovens vivenciam conjuntamente a instituição militar conhecida como efebia, um ritual de iniciação masculino. Em que pese a efebia ser exclusiva do universo masculino, desenvolvemos a ideia de os heróis formarem uma unidade, uma única persona - o vingador/justiceiro; portanto, ambos participariam do mesmo ritual. Comparamos alguns aspectos da instituição com as ações desenvolvidas pelos protagonistas e cogitamos da possibilidade de assistir, no nível do texto poético, a uma efebia trágica.
\end{abstract}

PALAVRAS-CHAVE: Eurípides; Electra; efebia.

ELECTRA AND ORESTES: THE EURIPIDEAN EPHEBES IN THE KHORA OF ARGOS
* Doutora em História pela Universidade de São Paulo. Professora de História Antiga na Universidade do Estado da Bahia.

\begin{abstract}
This article aims to analyze the Electra by Euripides, under a specific point of view - the examination of ephebeia. The drama of exclusion-inclusion of Electra and Orestes, added to the action space, the border, has led us to surmise that these young people experience together the military institution known as ephebeia, a male initiation ritual. Despite the ephebeia should be exclusively part of the male universe, we developed the idea that the heroes form a unity, only one persona - the avenger/vigilante; therefore, they both would participate in the same ritual. We compared some aspects of the institution with the actions taken by the protagonists and theorized the possibility of watching, on the poetic text level, a tragic ephebeia.
\end{abstract}

KEYWORDS: Euripides; Electra; ephebeia.

$\mathrm{P}$ or volta de 415 a.C., Eurípides leva aos palcos Electra, talvez um pouco posterior à encenação da peça homônima de Sófocles, e cerca de 40 anos depois de Ésquilo celebrizar o mito em Coéforas. Das 32 tragédias que nos chegaram na íntegra, 
estamos diante do único exemplo onde é possível cotejar o mesmo mito sob três singulares fábulas poéticas. Aristóteles (Poética, IX, 1451b 25) bem observou: "não é necessário seguir à risca os mitos tradicionais donde são extraídas as nossas tragédias; pois seria ridícula fidelidade tal, quando é certo que ainda as coisas conhecidas são conhecidas de poucos, e contudo agradam elas a todos igualmente". Na sequência, Aristóteles pondera exatamente acerca da necessária permanência da essência mítica e nos oferece como exemplo o matricídio da tindarida: "se por um lado o poeta pode usar da liberdade para transitar pelo mito, por outro, não deve fazer alterações drásticas nos mitos tradicionais, como, por exemplo, mudar o destino de Clitemnestra e ela não ser assassinada pelo seu filho" (Poética, XIV, 1453b 25). Embora o cerne mítico permaneça inviolável, somos agraciados com diferenças substanciais de várias ordens, sobretudo em Eurípides, que se afasta marcadamente dos seus predecessores. Merece especial atenção a instigante opção espacial do poeta em transportar toda a ação cênica e o elenco para a khớra argiva. E não menos perturbador é se deparar com a heroína de punhal nas mãos, desferindo o golpe mortal contra sua mãe e se transformando em coautora do matricídio.

Nosso artigo pretende focalizar a tragédia Electra, de Eurípides, sob um ângulo específico - o exame da efebia (ephēbeía). Ao seguir os passos dos protagonistas, Electra e Orestes, na khóra de Argos, percebemos um jogo de espaço (físico) muito bem elaborado - ora a khóra soa como espaço de exclusão, ora como espaço de inclusão. O drama de exclusão/inclusão - que nasce a partir da exclusão dos príncipes do espaço palacial e passa sucessivamente pela inclusão na khóra, quando os heróis encontram condições favoráveis para executar seus planos, por uma nova exclusão após o matricídio, e se encerra com uma inclusão atípica -, somado ao espaço de ação, a fronteira, levou-nos a conjecturar que a Electra bem pode ser pensada em termos de uma peça com nítidos traços da instituição ateniense conhecida como efebia, um ritual militar de iniciação masculina.

Em que pese a efebia ser exclusiva do cosmo masculino, desenvolvemos a ideia de Orestes e Electra formarem uma unidade, uma única persona - o vingador/justiceiro; portanto, ambos participariam do mesmo ritual. Comparamos alguns aspectos da instituição oficial da efebia com as ações desenvolvidas pelos jovens e cogitamos da possibilidade de assistirmos, no nível do texto poético (e apenas nesse nível), ao ritual efébico de Electra e Orestes, que culmina com o matricídio. A partir daí, eles são expatriados da cidade; porém, o ritual militar não estaria completo e não faria sentido, posto que a finalidade da marginalização temporária do efebo é a reintegração ao seu ô̂kos. Eurípides, o único poeta que expulsou os jovens do lar paterno, inventa uma forma de reintegração absolutamente atípica, posto que ocorrendo em cidades estrangeiras. Por esse viés, podemos considerar que o ritual de efebia trágica foi devidamente concluído.

Justifiquemos desde já a proposta de leitura da tragédia que compreende os heróis como efebos trágicos. Se, para Orestes, ${ }^{1}$ existe certa zona de conforto, passível de transformá-

\footnotetext{
${ }^{1}$ O Orestes de Ésquilo é o pré-hoplita, o efebo de Pierre Vidal-Naquet (1983 e 1989) e o Orestes de Sófocles é o efebo de Eleni Gasti (2001).
} 
lo em efebo com alguma facilidade, assim como o são Telêmaco, Hipólito, Neoptólemo, Penteu e Íon (Zacharia, 2003, p. 124), não podemos dizer o mesmo em relação à Electra, uma mulher, que, como bem sabemos, passava por rituais especificamente femininos. Resta-nos então demonstrar que a heroína pode desempenhar a função de efebo ao lado do irmão. A premissa básica é perceber Electra e Orestes como uma unidade, partindo do princípio de que um complementa o outro. Busquemos de antemão uma sustentação explícita no texto euripidiano. Trata-se de uma afirmação proferida por uma divindade. Castor é incisivo ao se referir à determinação de exílio imposta aos irmãos após o matricídio: “o ato é comum a ambos e comum também o destino” (v. 1305). ${ }^{2}$ Não há, portanto, como desvincular a ação de Orestes daquela de Electra; ambos passam por um ritual de passagem ${ }^{3}$ que dará a eles o estatuto de adultos: Electra estará pronta, enfim, para verdadeiramente se casar e procriar, e Orestes para assumir um novo ôkos. A semelhança e a complementaridade da ação desempenhada pelos personagens leva-nos a acreditar que ambos se submetem a um único ritual - a efebia. Os irmãos formam parte de um todo, uma espécie de alter ego, lutando por um ideal comum e sujeitos às mesmas desventuras. Observamos como um complementa o outro, e juntos resguardam os valores essenciais à vida na pólis: por vezes Electra é viril, perspicaz e racional, enquanto Orestes é sensível, sensato e emotivo; ambos conjuntamente são aguerridos, valentes e patriotas. Enfim, eles são dupla e unidade a um só tempo. Certamente não é por acaso que Vidal-Naquet (1988, p. 157) afirmará: “ $\mathrm{Na}$ verdade, pode-se efetivamente confundir Orestes com Electra, seu duplo". Eurípides parece desenvolver profundamente esse sentido de unidade, de uma única persona - o vingador/ justiceiro - representada em sua dualidade: Electra e Orestes.

Se, por um lado, a instituição da efebia é exclusiva do gênero masculino, por outro, nesse mundo de inversões, tal qual o do mito euripidiano, ela comporta aspectos femininos: "o travestir feminino do qual nós encontramos um exemplo na procissão das Oscofórias tem sido para as sociedades gregas arcaicas, como de resto para outras sociedades, um meio de dramatizar o acesso do jovem à virilidade e à idade do casamento" (Vidal-Naquet, 1983, p. 167). Não só aos meninos estava reservado o espaço de inversões, na procissão mencionada - as "mulheres se banqueteavam com homens" (Florenzano, 1996, p. 38). A antítese virilidade-feminilidade pode ser atestada em diversas passagens da peça em análise: em um extremo, ao incitar o irmão a matar a mãe, não se acovardando (v. 980-5), e segurar com ele o punhal matricida, tornando-se coautora do sacrifício (v. 1220-5), papel designado exclusivamente ao sexo masculino, Electra assume posturas eminentemente de

\footnotetext{
${ }^{2}$ Mencionamos apenas os versos quando se tratar da Electra euripidiana. Utilizamos a tradução de Karen Amaral Sacconi (2012).

${ }^{3}$ Maria Beatriz Florenzano (1996, p. 6-7) tratou de diversos rituais de passagem, entendidos como momentos de transição, ruptura de uma etapa a outra da vida, cercados de rituais e cerimônias específicos.

${ }^{4}$ Vidal-Naquet (1988, p. 157) faz menção aos versos 165-170 das Coéforas de Ésquilo, quando Electra e o coro encontram um cacho de cabelo sobre o túmulo e o coro questiona se a oferenda era de um homem ou de uma mulher. Eis que Vidal-Naquet conclui, então, com a transcrição em apreço.
} 
homem; em outro extremo, ao demonstrar piedade excessiva para com a mãe, tanto antes do assassinato quanto no momento posterior (v. 1205ss), inclusive ao cobrir os olhos com um pano no exato instante em que cometia o crime (v. 1220-5), Orestes desvela atitudes típicas do universo feminino. Nada disso, entretanto, faz de Electra menos mulher ou de Orestes menos homem. Por um lado, ambos atravessam uma fase de transição, estando sujeitos a distorções/inversões; por outro lado, esses comportamentos, de certa forma invertidos, ilustram bem essa complementaridade e esse duplo que defendemos.

Corrobora a nossa proposta o pensar a Electra a partir de algumas situações de inversão, particularmente sob a ótica de Froma Zeitlin. Em 1965, a autora publicou o artigo "The Motif of the Corrupted Sacrifice in Aeschylus' Oresteid" em que defendeu para a trilogia esquiliana, prenhe de imagens e metáforas, o conceito de "sacrifício corrompido", entendido como o fato de que "as ações violentas de derramamento de sangue são retratadas não como assassinato, mas como assassinato com roupagem sacramental, isto é, uma chacina ritual"' (1965, p. 464).

Em artigo publicado em 1970 e reeditado em 2003 - "The Argive Festival of Hera and Euripides' Electra" - Froma Zeitlin retoma o tema do sacrifício corrompido e o aplica à Electra euripidiana. Para a autora, à exceção dos dois rituais funerários - um feito por Orestes no início da peça e o outro pelo ancião, ambos sobre o túmulo de Agamenão -, os assassinatos de Egisto e Clitemnestra são rituais invertidos, sacrifícios corrompidos (2003, p. 268): o de Egisto ocorre no exato momento do sacrifício em honra às Ninfas e o de Clitemnestra é efetuado no instante em que se deveria sacrificar pelo nascimento do suposto filho de Electra. O que se percebe é que as mortes são retratadas como rituais, os animais que efetivamente deveriam ser sacrificados às divindades são, de uma certa maneira, substituídos pelos algozes da trama - Egisto e Clitemnestra.

A inversão ritual na Electra de Eurípides não se prende apenas aos sacrifícios dos monarcas. Assistimos também ao "matrimônio corrompido". A autora atém-se aos casamentos distorcidos de Clitemnestra e Electra. Zeitlin aponta três elementos inerentes ao casamento expostos na peça - o nascimento de uma criança, o status social (Electra se casa com um camponês) e a paixão sexual. Electra é penalizada em todos esses aspectos, enquanto Clitemnestra é plenamente satisfeita.

Os casamentos de mãe e filha voltam à cena com muita força na surpreendente metáfora da morte (Zeitlin, 2003, p. 283). Electra, submetida a um casamento tão atípico quanto possível, considerava-o como a própria morte: “Contraí núpcias, estrangeiro, núpcias mortais" (v. 247). A jovem, ao atrair a sua mãe ao seu casebre com a pretensa finalidade de realizar o ritual pelo nascimento do suposto filho, pretende ir além do cumprimento do oráculo apolíneo que vaticinava o matricídio. Electra aproveita-se da oportunidade para propiciar à genitora um casamento tão mortífero quanto o seu. Exatamente o que ela faz, através da linguagem, quando Clitemnestra se põe ingenuamente a entrar em sua casa para se apossar do cesto ritual. A filha anuncia enigmaticamente à mãe a morte funesta fazendo uso da metáfora do casamento: "Desposarás também no palácio de Hades aquele com quem te deitavas em vida" (v. 1140-5), alusão ao encontro da mãe com Egisto no reino 
dos mortos. Mãe e filha: a jovem morreu ao se casar com um camponês, transformando o casamento em morte; a mãe morreu ao assassinar o próprio marido, transformando a morte em casamento no Hades.

Partindo do princípio de que a peça comporta inúmeras inversões e está fortemente ancorada na ideia de ritual corrompido, vislumbramos a possibilidade de interpretar a trama euripidiana a partir de um novo prisma - a efebia de Electra, entendendo a passagem de uma mulher pela efebia como uma corrupção do ritual, de cunho exclusivamente masculino. Metáfora amparada, em parte, na ação de Electra ao coempunhar o punhal matricida (v. 1225), transformando-a em agente de um sacrifício. Nessa perspectiva, vejamos então como é possível, a partir da leitura poética da tragédia, buscar em um subtexto elementos para tornar sustentável a nossa abordagem. E assim, justificada a intromissão de Electra na efebia, partamos para o segundo momento: perceber traços da instituição ateniense na peça em apreço.

É do século IV a.C. a primeira inscrição que nos chegou com o termo efebia (Florenzano, 1996, p. 31). Temos poucas informações sobre a instituição no século V a.C., mas há certo consenso de que aquelas posteriores a esse século sejam também aplicáveis a ele em grande medida. O homem grego, para atingir o pleno estatuto de cidadão (a sua "agregação definitiva" à comunidade), deve, por um lado, casar-se e, por outro, participar da falange de hoplitas, do exército ou da marinha; enquanto essas duas condições não se realizavam, sobretudo a segunda, especialmente na Atenas clássica, restava uma grande ambiguidade - o jovem participava e não participava da cidade a um só tempo (Vidal-Naquet, 1983, p. 152-3). Ou seja, ele tinha uma identidade imprecisa; imprecisão muito semelhante à que queremos ver nos efebos trágicos.

Para alçar à condição de hoplita, o jovem deve passar pelos ritos iniciáticos da efebia. Havia duas modalidades: uma primeira, mais arcaica, que consistia na inscrição do jovem de dezesseis anos em sua fratria (Vidal-Naquet, 1983, p. 155). O ritual, realizado pelo pai, ocorria anualmente na festa das Apatúrias, no mês de Outubro (Pianépsion): consistia do Koúreion - o sacrifício animal e a oferenda do cabelo do jovem. A segunda efebia era a oficial, aquela que se iniciava aos dezoito anos e tinha a duração de dois anos.

Detenhamo-nos rapidamente nos versos 90-91, nada desprezíveis no contexto da discussão sobre efebia: o curto relato de Orestes da sua visita ao túmulo paterno, sua primeira medida ao chegar a Argos. Embora possa passar despercebido, esse momento é crucial. É o instante em que ele reassume o posto de filho de Agamenão, especialmente como seu herdeiro patrimonial e político. Reconhecendo-se como filho de Agamenão, ele reassume também a sua ligação com a terra de Argos, a sua fratria, superando a sua condição até então de exilado. Diante do túmulo, com o rosto tomado em lágrimas, Orestes inicia um ritual: corta uma mecha de cabelo e a depõe sobre o altar; em seguida, imola um carneiro e esparge o sangue nesse mesmo local. Ao observar com mais acuidade, poderíamos conjecturar que toda essa encenação equivaleria à primeira efebia: estava realizado o Koúreion, de que Orestes se incumbiu sozinho, pois seu pai jazia há muito dentro da tumba, e só na condição de morto podia assistir o filho. Tendo a sua identidade, de certa forma, restabelecida para 
si, para o pai e para a terra natal, Orestes podia, enfim, dar sequência aos seus planos, em uma segunda efebia.

No capítulo 42 da Constituição de Atenas, Aristóteles nos apresenta um esboço do ingresso do jovem na efebia e do seu funcionamento. Filhos de pai e mãe atenienses são inscritos em seus démotas ao completarem dezoito anos. Verificado o preenchimento dos pré-requisitos, o Conselho homologa as inscrições. Em seguida, deve-se formar o corpo 'técnico', que cuidará da educação dos efebos. Os pais dos jovens reúnem-se por tribo e elegem dentre os membros da tribo aqueles com mais de 40 anos, três dos melhores para se encarregarem dos jovens. Dentre esses, o povo elege um preceptor para cada tribo, e dentre a totalidade dos atenienses, um diretor sobreposto a todos. Em acréscimo, o povo elege dois treinadores e os instrutores que lhes ensinam a combater como hoplitas, a atirar com o arco, a lançar o dardo e a disparar a catapulta. Resumindo, a cidade dispensa à educação do efebo um diretor geral, dez preceptores, dois treinadores e um número não identificado de instrutores. Francisco Murari Pires (1995) explica em sua tradução da Constituição de Atenas a função de alguns desses instrutores:

O preceptor [um de cada tribo] ('sophronistés') cuida de infundir nos jovens cidadãos as virtudes condizentes com a 'prudência' ('sophrosýne), corrigindo exemplarmente suas falhas a esse respeito [...] Já o diretor ('kosmetés') [um sobreposto a todos] estaria encarregado de ensinar os preceitos respeitantes à ordem e à disciplina, preceitos esses especialmente condizentes com os princípios de formação e modos de combate da falange hoplita (Murari Pires, 1995, p. 239).

Orestes e Electra são os nossos perípoloi. Segundo Vidal-Naquet (1983, p. 153) este era o nome oficial dos efebos nos séculos V a.C. e IV a.C., cujo significado é aqueles que giram em torno de, fazendo referência tanto à condição ambígua do efebo, de estar e não estar na cidade, como dissemos acima, quanto ao seu espaço fronteiriço de atuação.

Tomamos de empréstimo do ensaio "Le chasseur noir et l'origine de l'éphébie athénienne" de Pierre Vidal-Naquet (1983) algumas das premissas consagradas aos efebos (o espaço fronteiriço, a caça, a participação nos festivais das Apatúrias e das Oscofórias, a inversão simétrica, a idade dos efebos). O ensaio foi produzido na década de setenta, devedor de contribuições como a de Henri Jeanmaire, de 1939, de Angelo Brelich, de 1960, de van Gennep, de 1913, dentre outros. Muitos trabalhos foram elaborados a partir do modelo de Vidal-Naquet, e o próprio helenista o utilizou em 1971 em "O Filoctetes de Sófocles e a efebia" com a intenção de, segundo ele, "complementar e ilustrar sua pesquisa anterior" (Vidal-Naquet, 1999, p. 125). Nessa mesma obra, no capítulo intitulado "A caça e o sacrifício na Oréstia de Ésquilo", Vidal-Naquet explora pormenorizadamente as metáforas de caça e de sacrifício na trilogia esquiliana e a íntima relação entre os dois temas. Nos anos noventa, Vidal-Naquet retornou ao seu chasseur noir (1992), mas as bases da efebia, lançadas nos anos setenta, persistiram inalteradas. 
Em 2003 foi publicado o livro Initiation in Ancient Greek Rituals and Narratives, organizado por David B. Dodd e Christopher A. Faraone, fruto de discussões de um congresso americano que se propunha a discutir a validade do conceito de rito de iniciação proposto por van Gennep. Nesse volume, Irene Polinskaya escreveu um instigante capítulo "Liminality as metaphor: initiation and frontiers of Ancient Athens". Polinskaya tenta desconstruir em certa medida o modelo do caçador negro de Pierre Vidal-Naquet (1983). O problema central gira em torno da abordagem estruturalista sobre as fronteiras, observadas em uma rígida oposição binária: de um lado a fronteira selvagem, não civilizada (espaço do efebo) em oposição ao centro, civilizado e ligado à cultura (espaço do hoplita/cidadão). Polinskaya se inquieta com a dimensão que tomou o trabalho de Vidal-Naquet, empregado muitas vezes de forma acrítica, segundo pensa. A partir de evidências arqueológicas e epigráficas, Polinskaya se detém no estudo das fronteiras atenienses, na tentativa de reverter a concepção de fronteira como espaço selvagem e inóspito, afastado inteiramente da comunidade. Os fortes atenienses, espaço dos efebos, localizados nas fronteiras, como Elêusis e o Súnio, por exemplo, contavam com uma habitação densa, com uma produção agrícola e com recursos financeiros. Ademais, mais da metade da população ateniense morava no campo e muitas pessoas que moravam no espaço urbano tinham suas propriedades no campo, inclusive nas fronteiras. Nesse sentido, o território não era um espaço de isolamento, posto que havia uma interdependência entre campo e cidade. Por essa ótica, pensar o efebo ateniense como um sujeito completamente isolado da comunidade não faz sentido. Os jovens patrulhavam o território e se faziam presentes em inúmeras atividades públicas. Tudo isso proporcionava, consequentemente, o contato e não o isolamento.

A caça ligada exclusivamente ao agrós, à eskhatiá, como sugere Vidal-Naquet, também é questionada por Polinskaya, posto que essa atividade era executada em vários locais, inclusive próximo às habitações, e nada leva a crer que os efebos de Atenas praticassem a caça como em Esparta. Por fim, acrescenta Polinskaya, a eskhatiá apresentada como espaço selvagem e não cultivado, de lenhadores e pastores, não condiz com os estudos mais recentes, que demonstram que havia mais eskhatiai cultivadas/produtivas do que o contrário. Apesar de todas as considerações, Polinskaya não invalida o modelo de Vidal-Naquet, mas adverte quanto ao seu entendimento literal e sugere que a ligação entre mito e prática social é melhor entendida como procedimento metafórico, uma vez que a relação entre a prática social e o mito não é tão óbvia (Polinskaya, 2003, p. 85-106).

Em nosso entendimento, as observações de Irene Polinskaya não prejudicam a utilização que fazemos do modelo de Pierre Vidal-Naquet, pelo contrário, suas ponderações quanto à eskhatiá e ao espaço fronteiriço como um todo são absolutamente pertinentes ao se observar a Electra euripidiana. O espaço além-muros, para onde o poeta remete toda ação, é dinâmico, pujante, com suas fazendolas, inclusive a do ancião, bastante produtiva, localizada em uma eskhatiá (nos limites de Argos com Esparta). As pessoas transitam pelo campo, vão ao palácio, saem do palácio e fazem o caminho inverso (para o campo); as notícias circulam, o ancião sabe o que se passa no palácio e um pastor noticia o Festival de Hera próximo a 
acontecer. Portanto, estamos de acordo com Polinskaya ao afirmar a interdependência entre os espaços urbano e rural e refutar a concepção dicotômica de eskhatiá. ${ }^{5}$

Nesse espaço vivo, nossos heróis, tais quais os efebos de Atenas, não estão sozinhos. Podemos afirmar que o espaço de fronteira possibilita a formação de um grupo, cujos membros são plenamente incluídos, desde o camponês pobre, passando pelo ancião exilado, até chegar aos servos de Orestes. Cada membro desempenha uma função e o comando, como no caso dos efebos de Aristóteles, cabe a um diretor geral. Conheçamo-los: Pílades e o séquito de servos que Orestes trouxe consigo; enquanto desse séquito sai o mensageiro, Pílades, a despeito de não possuir uma única fala na trama, é o mais fiel de todos os companheiros, a sombra de Orestes. Electra chega a coroá-lo, afirmando, sem hesitação, que ele lutou ao lado do seu irmão "de igual para igual” (v. 885ss) no assassinato de Egisto. Electra, por seu turno, estava casada com um camponês que, ao contrário do que previa Egisto, era o mais nobre dos nobres, de ilibado caráter e desmedido desprendimento, um membro ideal para engrossar o exército de Orestes. Os efebos trágicos podiam contar também com o leal coro de mulheres argivas sem exclusão (v. 273), que comungava com o mesmo desejo dos irmãos, a morte de Clitemnestra (v. 485-6), e alegrou-se com o assassinato de Egisto (v. 860ss). Fechando o grupo, estava o elemento mais importante deles, a quem denominamos de diretor dos efebos: o ancião. Ele ocupa um papel sobressalente na trama: a) na preparação de Orestes para a sua mais difícil caçada: Egisto; b) no auxílio aos planos matricidas de Electra, como mensageiro; c) do ponto de vista econômico, ao alimentar a comitiva do príncipe.

Orestes sabia que retornava à cidade para cumprir o oráculo. Tudo que tinha em mente, no entanto, era encontrar a irmã, torná-la cúmplice do assassinato, e entender o que estava acontecendo na ásty ("cidade", v. 98-101). Nesse sentido, o Orestes de Eurípides é muito diferente daquele sofocliano, que chega à cidade completamente decidido e com todo o plano muito bem arranjado. No entanto, Eurípides nos revela uma agradável surpresa: ele faz ressurgir o velho preceptor de Agamenão em uma posição de absoluto relevo na peça. Ausente da versão esquiliana, ele se faz notar em Sófocles de modo enaltecedor.

$\mathrm{O}$ ancião, na versão de Eurípides, estava diante agora da chance de ver restituída a função que outrora ocupara (preceptor de Agamenão), não mais do velho Agamenão, que ele soube instruir tão bem, mas dos seus filhos, Electra e Orestes. Caberá a essa figura dramática grande parte dos planos de assassinatos. Ouçamos o príncipe e tiremos as nossas conclusões:

E tu, velho - pois na hora certa vieste - / fala: o que faço para me vingar do assassino de meu pai?/ E da mãe, partícipe de casamentos profanos?/ Tenho algum apoio dos amigos em toda Argos?/ Ou em tudo estou arruinado, como os meus fados?/ A quem me unir? De noite ou durante o dia? / Para qual via nos voltamos contra meus inimigos? (v. 598-604).

\footnotetext{
${ }^{5}$ Remetemos ao artigo de M. Giangiulio, publicado em 2001, em que ele retoma, com base em uma documentação epigráfica, o conceito de eskhatiá e o exprime sob novas bases.
} 
Orestes, embora determinado, como um efebo nas montanhas, precisa ser capacitado. O herói sabe o que deve fazer, porém ignora a forma de atuação: ele não possui um plano, não sabe se tem com quem contar e nem a que horas deve agir. Urge que o ancião assuma o comando. Serenamente, o sábio ancião lhe diz que ele não tem ninguém ao seu lado, porém "nas tuas mãos [de Orestes] e no teu destino tens tudo/ para tomar a casa paterna e a cidade [pólis]" (v. 610-1). O jovem continua sem entender o alcance das palavras do velho homem. Pacientemente, como todo bom instrutor, o ancião o instrui passo a passo e quando sente, enfim, que o seu efebo está pronto, diz-lhe: "Pensa tu mesmo a partir daí, conforme os acontecimentos" (v. 639).

A tarefa designada pelo ancião a Orestes é matar Egisto e Clitemnestra (v. 613), como já previra o oráculo. Acompanhemos as instruções do ancião: 1) tudo deve ser feito além das muralhas tomadas pelos guardas e lanceiros de Egisto (v. 616); 2) Orestes deve ir à propriedade rural onde Egisto irá realizar um rito às Ninfas (v. 623-7); 3) em seguida, Orestes deve deixar que Egisto o veja naturalmente e, vendo-o, o convidará para o banquete (v. 637); 4) apenas escravos acompanham Egisto, e estes passarão para o lado de Orestes, se ele vencer (v. 629-33).

Orestes, pensando que fosse encontrar as vítimas - Clitemnestra e Egisto - no mesmo lugar, fica sem saber como efetivar os dois assassinatos (v. 646). Nesse momento Electra assume as rédeas da trama: "Eu mesma prepararei o assassinato de minha mãe" (v. 647). Nesse instante, o ancião dará os seus préstimos a Electra, ao se dispor a levar uma mensagem da princesa à mãe com o objetivo de atraí-la a sua casa. O recado tem o seguinte teor: a princesa teve um filho há dez dias e pede à mãe para ir a sua casa realizar o ritual de nascimento. Nesse ambiente de fronteiras, Clitemnestra deverá morrer (v. 652-62).

Por fim, segundo Aristóteles (Constituição de Atenas, XLII), cada um dos preceptores recebe a quantia relativa aos membros de sua tribo e compra as provisões para todos em comum; eles se alimentam conjuntamente por tribo e tomam todas as demais providências. $\mathrm{Na}$ peça, o ancião é chamado à casa de Electra, para oferecer um jantar de boas vindas. Ele responde de pronto, levando consigo comida, bebida e coroas de flores para a manutenção do grupo. Todos se alimentam coletivamente. O ancião, portanto, preenche mais essa função, apontada por Aristóteles como a do preceptor dos efebos - prover materialmente o grupo. Assim sendo, parece-nos que boa parte das atribuições do corpo de preparadores dos efebos pode ser distinguida em alguma medida no ancião, permitindo-nos afirmar que o homem velho, expulso da cidade e de origem servil, é o personagem de maior envergadura na trama euripidiana, sem o qual Orestes e Electra teriam muitas dificuldades em sobreviver jogados às feras (Clitemnestra e Egisto) nas fronteiras, tanto quanto os efebos aristotélicos, se não dispusessem de bons instrutores.

Traçados os planos, Electra diz ao irmão: "Já tens o teu trabalho. Cabe a ti o primeiro assassinato" (v. 668). Orestes responde com firmeza que já estaria a caminho se houvesse um guia para lhe mostrar o local da propriedade onde ele encontrará Egisto; o ancião rapidamente se põe a postos como seu guia (v. 670). Antes da partida, juntos, suplicam aos deuses da família e aos mortos aliados, para a boa fortuna da empreitada. Na sequência, 
Electra dá ao irmão o último conselho/aviso: "É preciso que te tornes homem para isso./ Anuncio a ti: Egisto deve morrer” (v. 684-5). Tornar-se homem ${ }^{6}-$ cidadão pleno, apto a tomar as decisões que a vida política exige - é exatamente o objetivo da efebia, justamente aquilo de que Electra impele o irmão a não se esquecer, a tomar como sua meta prioritária. Para tanto, é necessário ao jovem a marginalização temporária, o afastamento do seio da sociedade para vivenciar um ritual de iniciação, aquilo que Vidal-Naquet (1983, p. 163) denomina de 'inversão simétrica'. Sabemos, por intermédio de Aristóteles (Constituição de Atenas, XLII, 4-5), que no primeiro ano da efebia o jovem era treinado pelos instrutores, no segundo ano ele deveria fazer uma demonstração de manobras militares, exibindo o resultado do aprendizado, em uma assembleia realizada na orquestra do teatro, quando recebia do Estado um escudo e uma lança para patrulhar o campo, estacionado nos postos de guarda, trajando as suas clâmides negras.

Electra, como se consciente de tudo isso, está chamando a atenção do seu irmão, como que reforçando a ideia de que urgia superar a infância e ultrapassar de vez o limite da adolescência para a idade adulta. Ou seja, exatamente esse período de transição a que corresponde a efebia, quando, ao final, o jovem encontra-se apto a se integrar completamente à vida social ao lado dos demais cidadãos (Aristóteles, Constituição de Atenas, XLII, 5; VidalNaquet, 1983, p. 152). O tempo em que os protagonistas corriam brincando, crianças que eram, atrás de pequenos animais, como a corcinha (v. 574), ficou para trás. Era chegada a hora de empreender grandes caçadas na orquestra do teatro convertida em fronteira argiva, momento único de adquirir e expor a sua honra (timé $)$ à altura de autênticos herdeiros de Agamenão: a Orestes cabia destruir o touro, Egisto (v. 816), enquanto Electra se incumbia de vencer a leoa (v. 1163), ${ }^{7}$ Clitemnestra, com o auxílio do irmão. Orestes nada responde ao

\footnotetext{
${ }^{6}$ Alain Moreau registra semelhante passagem no canto I da Odisseia, quando a deusa Atena, disfarçada de Mentes, aconselha Telêmaco a ir buscar notícias sobre o pai, em Pilos e em Esparta. Após instruílo, a divindade o adverte que, quando ele retornar da sua viagem (iniciática para Moreau), ele deverá pensar como afastar os pretendentes de sua casa, chamando sua atenção exatamente para os versos 296-7, quando ela acentua que Telêmaco deve deixar os jogos de criança, posto que essa fase já passou (Moreau, 1992, p. 233-4). Mais interessante é que, na sequência, Mentes pergunta a Telêmaco: se acaso "não terás ouvido da fama que granjeou o divino Orestes/ entre todos os homens, quando matou o assassino de seu pai,/ Egisto ardiloso, porque este o pai glorioso lhe matara?" (Homero, Odisseia, I, v. 298-300).

${ }^{7}$ No caso de Egisto, o touro, duas passagens abalizam a nossa assertiva: a) quando o rei se refere à fama dos tessálios, crendo ser Orestes um deles, de bons destrinchadores de touros (v. 815-6), Orestes provará que sim. No entanto, eis que o touro que ele "destrinchará” será o próprio Egisto; b) quando Electra encaminha Clitemnestra para a morte, ela lhe revela que a "cesta está pronta para o início do sacrifício e a faca está afiada, /aquela própria para abater o touro, perto de onde cairás / golpeada" (v. 1142-4). Somos levados a pensar que o touro a que se refere Electra seja exatamente Egisto, que já foi abatido. Froma Zeitlin (2003, p. 276) também faz alusão a Egisto como touro: "Electra, antes do assassinato de Clitemnestra, fala do touro sacrificial, Egisto (v. 1142-4)". Quanto à analogia de Clitemnestra, a leoa, observemos como no kommós, quando tudo dentro da casa de Electra está preparado para o momento fatal do matricídio, o coro relembra a morte impiedosa de
} 
último apelo da irmã e, com passos firmes e armado tanto quanto possível (ele reage aos escravos de espada em punho, v. 847), ele está preparado e, sem dar palavra alguma, segue resoluto. Dessa forma, resta à Electra concluir o segundo episódio, tecendo conjecturas sobre o desfecho do plano, se venturoso ou fracassado. No entanto, nesse instante, no exato momento em que Electra o desafiava a tornar-se homem, Eurípides bem poderia ter colocado na boca do seu herói/efebo algo como o juramento, segundo Vidal-Naquet, pronunciado pelos efebos quando, provavelmente, concluído o estágio de aprendizado, recebiam as suas armas na festa das Apatúrias, e eram alçados enfim ao estatuto de hoplitas (1983, p. 164):

I - Não desonrarei essas armas sagradas; II - Não abandonarei o meu companheiro de combate em qualquer linha de batalha em que eu estiver; III - Eu defenderei nossas instituições sagradas e públicas; IV - E eu não transmitirei (aos descendentes) uma pátria diminuída, mas ainda maior e melhor, tanto quanto eu seja capaz sozinho ou com a ajuda de todos; V - Obedecerei àqueles [aos magistrados] cujo exercício seja razoável, às leis estabelecidas e às que forem razoavelmente estabelecidas no futuro; VI - Se alguém pretender anulá-las, eu não admitirei, tanto quanto eu seja capaz sozinho ou com a ajuda de todos; VII - Honrarei as instituições sagradas tradicionais [...] (Siewert, 1977, p. 103).

Nada seria mais apropriado a Orestes do que esse discurso, como fizera Sófocles, segundo Siewert (1977, p. 105-7), inserindo em sua Antígona (v. 663-71) ecos do juramento cívico. Não foi esse o desejo de Eurípides, embora em seu efebo caiba cada uma das premissas presentes nesse extrato: o herói das montanhas argivas não desonrará a lei divina preconizada no oráculo que traz consigo; não abandonará a irmã e a cidade aos desmandos de Egisto - um rei injusto. Pelo contrário, libertá-la-á dos usurpadores do trono, lutando incansavelmente com o auxílio daqueles que se postarem ao seu lado; ele também não questionará as leis justas da cidade, quando tiver de abandonar definitivamente a sua pátria, e honrará as instituições sagradas como um todo.

Assistamos então à caça dos protagonistas euripidianos. Lembremos antes, porém, de que Egisto também caçava Orestes. Entretanto, pelo que conhecemos da sua personalidade, tal caçada fugiria aos padrões da de um verdadeiro herói. O rei não empreenderia a caça, antes, terceirizaria a ação: "prometeu ouro a quem o [Orestes] matasse" (v. 33). Voltemo-nos, assim, a uma caça verdadeiramente heroica. Para Vidal-Naquet (1983, p. 169) a caça está ligada ao agrós, à região da eskhatiá, e é atividade normal dos heróis, modelos dos efebos, e, parafraseando F. Orth (1914), Vidal-Naquet diz que todos os heróis são caçadores e todos os caçadores são heróis; a iniciação espartana conhecida como Krypteía é em certo sentido

Agamenão pelas mãos da rainha: "Tal qual leoa de uma montanha de terras férteis/ que habita a mata, isso ela consumou" (v. 1163-4). Trata-se, portanto, de "sacrifícios corrompidos", como vemos na interpretação de Froma Zeitlin (2003). Para Alain Moreau, figuram entre as marcas distintivas do efebo as provas em que eles enfrentam gigantes, bestas ferozes e monstros, um desses exemplos é o Orestes de Ésquilo ao matar Clitemnestra qualificada como monstro (1992, p. 220). 
uma caçada aos hilotas. A caça compunha um dos pilares da educação tradicional e era central na introdução do jovem aos valores morais da pólis (Chevitarese, 2000, p. 209), e, não por acaso, o adolescente aparece ligado à caça solitária com redes, conforme acentua Vidal-Naquet (1983, p. 179).

A caça pairava não só na realidade de uma elite como no seu imaginário, inclusive infanto-juvenil. Eurípides opta por um elemento definitivamente novo para nos apresentar a cena de reconhecimento (anagnórisis) entre Orestes e Electra: um sinal proveniente de uma situação singular. É observando detidamente o hóspede de Electra que o ancião reconhecerá nele, através de uma cicatriz, Orestes. A princesa resistiu de forma implacável a acreditar em inúmeras evidências, entretanto, rendeu-se cabal e imediatamente à prova daquele sinal no supercílio do irmão, provocado pela queda da então criancinha ao perseguir/caçar um filhote de corça, quando ambos brincavam (v. 570-5). Se, por um lado, quando o ancião a instigou sobre a possibilidade de ter feito um traje para o seu irmão, que agora servisse como prova do seu retorno, ela não se lembrava, e ainda zombou do velho, afastando tal possibilidade (v. 535-45), por outro, porém, estava vívida em sua memória a caça empreendida por ela e pelo irmão quando pequenos. Duas atividades igualmente fundamentais na educação dos jovens: à menina cabia a tecelagem e ao menino a caça. É revelador que a memória de Electra volte-se tão só à tarefa masculina - a lembrança da caça - muito apropriada a um personagem inteiramente viril, incorporado em um efebo.

A caçada infantil foi malograda e terminou por deixar sequelas no nosso herói. Aquela cicatriz representa mais uma vez um sinal - sinal de que só a vitória interessa. A estes jovens efebos, novamente reunidos em uma caçada, postos agora a uma prova definitiva, cabe unicamente o sucesso da empresa; caso contrário, bem sabem, aguarda-os a morte (v. 686ss) e não outra cicatriz. Parte da caçada cabe apenas a Orestes; em seguida, ele deve retornar trazendo a sua caça abatida (Egisto). Na sequência, sem descanso, é a vez de, junto com a irmã, empreender nova caçada e subjugar mais uma presa (Clitemnestra).

Duas estratégias de caça são utilizadas: Orestes sai para a sua caçada noturna ${ }^{8} \mathrm{em}$ perseguição a sua presa, enquanto Electra monta uma armadilha para atrair a sua. Em ambas, contudo, vemos um elemento comum: a apátè, um ardil. $\mathrm{O}$ ardil é o oposto do comportamento leal, adequado ao hoplita (Vidal-Naquet, 1983, p. 157; Florenzano, 1996, p. 37-8).

Segundo Vidal-Naquet (1983, p. 155-7) e Florenzano (1996, p. 37-8), as festas das fratrias - as Apatúrias - relembram a disputa da fronteira entre a Ática e a Beócia, uma eskhatiá. O conflito tem como objeto o domínio tanto sobre Oinoé e Panacton quanto sobre Mélainai (um dêmos da fronteira). O rei ateniense, Timoites, e o rei beócio, Xântio, conhecido como o Loiro, decidiram resolver a querela em um duelo individual (monomakhía). Como Timoites, o último representante de Teseu, já estava em idade avançada, Melântio, um campeão negro, dispôs-se a combater em seu lugar, segundo alguns textos, devido à promessa de sucessão. Com a substituição, o combate deveria ser decidido entre Melântio, o Negro, e Xântio, o

\footnotetext{
${ }^{8}$ Presumimos que seja noite quando Orestes e Egisto se encontram. Egisto acredita ter persuadido os estrangeiros a participar do banquete: "Se levantardes da cama cedo, / chegareis na mesma hora. Vamos, entremos na casa" (v. 786-7).
} 
Loiro. Melântio, fugindo às regras do modelo heroico de combate previsto, valeu-se de um ardil (apátê) para vencer Xântio. No momento decisivo, Melântio desviou a atenção do seu adversário quando lhe disse: 'Xântio, você não respeita as regras, tem alguém ao seu lado', insinuando que ele tivesse trazido alguém para ajudá-lo no combate. Quando o rei se distraiu para verificar acerca do que o seu adversário o questionava, foi surpreendido por Melântio, que o matou. O relato varia de um texto a outro. Vidal-Naquet (1983, p. 157) menciona que a maior parte deles faz referência à intervenção de Dioniso - "que é o Dioniso noturno em pele de cabra preta". Dioniso é frequentemente associado à efebia (Winkler, 1992, p. 2062) tanto quanto Apolo, um deus ambivalente, porquanto ligado tanto ao efebato quanto à ordem cívica dos já iniciados, os cidadãos (Zacharia, 2003, p. 116-24). Cornelia Isler-Kerényi (2007, p. 135) propõe Dioniso como patrono da efebia e analisa várias imagens nos vasos gregos apontando uma ligação entre o deus e o efebo.

Retornando à assertiva de Vidal-Naquet (p. 159-60), três aspectos chamam a sua atenção no relato acima, possibilitando-lhe relacionar o mito de Melântio com a festa das Apatúrias e com os efebos: 1) a localização fronteiriça do relato do mito que corresponde ao espaço de fronteira do juramento dos efebos; 2) o lugar que ocupa a apáté, comportamento oposto ao que se esperava do hoplita; 3) o dominante negro do relato, ou seja, o próprio nome de Melântio (de mélas, "negro”), o lugar do combate, em alguns textos - Mélainai, e a evocação ao Dioniso Melánaigis. Para Vidal-Naquet (1983, p. 159), "o negro não está isolado”. Nas Helênicas (I, 7, 8), Xenofonte nos diz que no contexto das Arginusas, durante a festa das Apatúrias, Terâmenes e seus amigos organizaram uma manifestação em que apareceram de roupas de luto e cabeças raspadas, passando-se por parentes dos mortos, o que, segundo Vidal-Naquet (1983, p. 159-60), pode dar a entender que no curso das Apatúrias os homens vestiam um hábito de luto e raspavam a cabeça assemelhando-se aos efebos, que usavam a clâmide negra e raspavam a cabeça. Conforme Vidal-Naquet (1983, p. 173) "o efebo ateniense é, em certo sentido, o herdeiro do caçador negro”. No esteio da bem tecida assertiva do helenista, verifiquemos o quanto do caçador negro está presente em nossa efebia trágica. Iniciemos investigando o traje dos nossos efebos.

Não há uma referência explícita quanto à cor dos trajes de Electra e Orestes. Contudo, não há como se duvidar de que as vestes de Electra, sempre descritas como muito sujas e confeccionadas por ela mesma (v. 300; 1107; 1108), representavam o luto paterno infindo vivido pela jovem. Não por acaso, as portadoras de libações de Ésquilo trajam "mantos negriemais" (Coéforas, v. 10-5) e Electra se distingue com "pranteado luto" (Coéforas, v. 1520). Kubo (1967, p. 23) registra que uma das distinções entre as jovens que compõem o coro e Electra, em seu encontro na cena do párodo, é exatamente o contraste entre as vestes coloridas e alegres das jovens e o traje de luto da princesa euripidiana. Quanto a Orestes, as alusões são ao seu estado geral de expatriado: "é fraco um homem exilado" (v. 352). A exceção é a menção a uma capa afivelada que Orestes retira para facilitar os seus movimentos na hora do sacrifício (v. 819-26); vemos em algumas representações imagéticas o efebo com uma capa afivelada. ${ }^{9}$

\footnotetext{
${ }^{9}$ Consultar < http://commons.wikimedia.org/wiki/File:Ephebe_uniform_MNA_Inv11107.jpg.
} 
Em relação à cabeça raspada dos efebos trágicos, Electra faz referência em mais de um momento a sua cabeça raspada; no verso 241, ela se compara a uma cita: "E a cabeça raspada com a navalha como uma cita". Diante dessas considerações, poderíamos afirmar que Electra se caracteriza perfeitamente como um efebo - trajando a sua "clâmide" negra e com os cabelos raspados. Poderíamos acrescentar que Orestes também tem os cabelos "raspados". É evidente que temos de frisar em letras garrafais que o jovem cortou os cabelos em um contexto inteiramente ritual/religioso; todavia, ele o fez exatamente quando entrou na cidade e realizou o Koúreion (cognato do verbo keírö, que significa cortar os cabelos).

Entendamos como foi possível aos efebos trágicos vencer o homem (Egisto) que não dormia (v. 616), o rei meticuloso que se cercou de todos os cuidados, mantendo um forte esquema de segurança (v. 616), atormentado pelos temores de uma armadilha por parte de Orestes (v. 831-3), e como foi fácil atrair à morte Clitemnestra, a rainha cercada de servos por todos os lados. Os nossos protagonistas tanto quanto Melântio, o caçador negro, lançam mão da apáté.

Guindado pelo ancião à primeira apátè, Orestes surpreende e faz desse recurso a sua arma mais poderosa. $\mathrm{O}$ ancião diz para Orestes que ele deve ir até o local onde Egisto está como se fosse um mero passante e deixar que o rei o veja naturalmente; ao vê-lo este o convidará para o banquete (v. 634-6). O ancião estava certo, Egisto comportou-se como previsto. Dado o passo inicial, era necessário Orestes conquistar a confiança da sua presa, fazendo-a crer que estava entre amigos. Desse modo, Egisto se voltaria completamente ao ritual às Ninfas, esquecendo momentaneamente a 'grande ameaça' que pairava sobre sua cabeça e, consequentemente, facilitando os planos do caçador. Com esse objetivo, Orestes se fez passar por um tessálio a caminho do rio Alfeu para sacrificar a Zeus Olímpio (segunda apátê). A sua origem chamou a atenção de Egisto, que logo associou o seu hóspede à fama dos tessálios, de bons destrinchadores de touro e domadores de cavalo (v. 815-7). No momento do sacrifício, Egisto degola uma novilha e, no que acreditamos uma gentileza do anfitrião para com o seu conviva, tanto quanto um desafio ou uma provocação, ele pede a Orestes para comprovar a boa fama do seu povo de hábeis destrinchadores:

E ele [Orestes] tendo se apoderado da faca dórica com a mão/ e jogado para longe dos ombros a capa afivelada,/ escolheu Pílades como ajudante nos trabalhos,/ repelindo os escravos, e, segurando o pé da novilha,/ despojou a carne branca, estendendo a mão./ Esfolou o couro mais rápido que um corredor/ termina o percurso duplo de ida e volta da corrida hípica,/ e deixou descobertos os flancos (v. 819-26).

Orestes faz toda uma teatralização (terceira apátê), criando um cenário favorável ao assassinato: ele se livra do excesso de roupas, afasta habilmente os escravos de Egisto, e com extrema perícia faz-se assemelhar a um atleta. Uma constatação, contudo, inquieta o rei, havia algo estranho no animal esfolado: "o lóbulo do fígado não estava entre/ as vísceras, e os orifícios de entrada, próximos à vesícula biliar/ revelavam um ataque iminente ao observador" (v. 827-9). Diante da reação de estranhamento de Egisto, o príncipe o indaga: 
"Por que estás preocupado?” (v. 831). Ele, então, confessa a situação limítrofe em que vive: teme uma armadilha do seu maior inimigo, Orestes (v. 831-4). Orestes mais uma vez tenta aplacar os temores da sua presa, minimizando-os, deixando o poderoso rei em situação constrangedora: "Então temes a armadilha de um exilado,/ sendo tu o senhor da cidade?" (v. 834-5). Assim, sincero ou não, desconfiado ou não, o rei, temendo o ridículo, não poderia demonstrar fraqueza; então ele continuou do alto da sua majestade, como se nada soasse anormal e o pavor não o dominasse. Orestes, como bom ator, finge superar completamente o episódio e prossegue: "Então, para nos banquetearmos / com a vítima, não trará alguém o cutelo da Ftia em vez/ do dórico, para fender o tórax?” (v. 835-7). A substituição da faca pode ser considerada mais uma medida ardilosa (quarta apátê), com o objetivo de novamente desviar a atenção da presa, prestes a receber o bote. Por fim, Egisto pega as vísceras para fazer a partilha e, quando ele se inclina, Orestes o atinge pelas costas, rompendo a sua coluna vertebral (v. 839-42). O efebo, Orestes, age exatamente como o caçador em relação à caça. Valendo-se de um conjunto de estratagemas, o herói pacientemente acua a presa e quando ela já não oferece nenhuma resistência, sem lhe dar qualquer chance de defesa, ele desfere o golpe mortal.

Electra planeja o matricídio (v. 652ss) usando uma dose ciclópica de apátēe ela finge ter dado à luz um bebê (sua isca) sem qualquer ajuda e, sozinha e desamparada, necessitar da mãe para realizar o ritual da décima lua da criança. Em seguida, ela envia o ancião como seu mensageiro ao palácio e consegue atrair Clitemnestra a sua choupana. Electra e a mãe conversam trocando duras farpas. Nesse ínterim, Orestes, seus servos e Pílades estão escondidos no interior da casa, onde também está ocultado o corpo de Egisto.

Coube a Orestes afastar os escravos das proximidades de onde o crime contra Egisto seria cometido, temendo alguma reação por parte deles. Electra terá a sua ação facilitada pela própria Clitemnestra, que dispensa as servas, ordenando-lhes retornar apenas após a conclusão do ritual (v. 1035-7). A princesa/caçadora encaminha a presa à armadilha: pede para a mãe entrar em seu casebre. Toda a cena está montada, o gatilho está prestes a ser disparado. Electra sentencia: "A cesta está pronta para o início do sacrifício e a faca está afiada,/ aquela própria para abater o touro, perto de onde cairás/ golpeada. Desposarás também no palácio de Hades/ aquele com quem te deitavas em vida" (v. 1142ss). Electra e Orestes permaneceram firmes no ato do matricídio. Orestes que sabia que a sua luta seria amarga, e a sua marcha, dolorosa (v. 984-6), uma vez incitado por Electra, leva a cabo o assassínio da mãe sem dar ouvidos à súplica de Clitemnestra (v. 1165).

A caça noturna, a armadilha e a apátè, mecanismos explorados pelos efebos trágicos, são plenamente justificáveis, dada a situação limítrofe em que se encontravam, bem semelhante à dos jovens espartanos, durante a Krypteía, lançados às margens, obrigados a sobreviver em condições atípicas, roubando e matando. (Plutarco, Vida de Licurgo, 36-37).

Além das Apatúrias, os efebos participavam também das Oscofórias - um espaço de inversões, de antíteses, que acontecia logo depois das Apatúrias. O festival comemorava o retorno de Teseu após a vitória sobre o Minotauro, e seus ritos reviviam o mito desse herói em sua saga cretense. Teseu venceu a fera, porém nem tudo saiu como esperado, pois 
o príncipe, embebido em seu feito, esqueceu-se de içar a vela que simbolizava o seu retorno seguro. O pai, Egeu, desesperado, acreditando que o pior acontecera ao filho, atirou-se do rochedo (Plutarco, Vida de Teseu, 22). Ao saber do que havia se passado, o herói foi tomado por sentimentos contraditórios: de um lado, ele estava feliz por vencer o terrível Minotauro, porém, de outro, a tristeza assolava a sua alma pela inesperada morte do pai (Vidal-Naquet, 1983, p. 160). Em situação semelhante estava o povo: de um lado, muitos gritavam de alegria com a vitória de Atenas e queriam coroar Teseu; por outro, muitos choravam a morte do rei. Plutarco diz que ainda em seu tempo, na festa das Oscofórias, no momento do sacrifício e das libações, aqueles que estão presentes gritam para rememorar esse episódio: 'Eleleu! Iou! Iou? - os primeiros gritos são de alegria e os seguintes de consternação e confusão (Plutarco, Vida de Teseu, 22).

$\mathrm{Na}$ Electra nós assistimos a duas situações que nos remetem às Oscofórias ou ao mito de Teseu. Partindo da ideia de Vidal-Naquet (1983, p. 160) de que Teseu é o efebo por excelência, nada mais apropriado do que a analogia entre ele e aspectos do mito no que respeita às Oscofórias com os efebos trágicos. A primeira situação de que falamos nos leva a uma cena de gritos dúbios, confusos. Orestes deixa a casa de Electra com a missão de executar a parte inicial do plano, assassinar Egisto, enquanto Electra permanece à sua espera, apreensiva, aguardando notícias. Passado um tempo, o coro ouve gritos ao longe e chama Electra, que está dentro dos seus aposentos. O coro diz apenas que escutou um gemido de morte. Quando Electra pergunta se o gemido é argivo ou dos seus amigos, o coro responde: "Não sei, pois todo som do grito está misturado" (v. 756). A tensão atinge seu ponto mais crítico: todo futuro dos efebos dependia do resultado que aqueles gritos confusos faziam ressoar ao longe. Diante do desespero de Electra, sentindo pairar a derrota, mas sem certeza alguma, as amigas pedem para ela aguardar, pois não é simples matar um rei (v. 757-60).

A segunda situação que nos remete às Oscofórias é a alternância de sentimentos de Orestes diante da decisão do matricídio. Se no que tange à morte de Egisto a alegria é generalizada, a começar por seus próprios escravos (v. 855), o mesmo não podemos dizer da morte de Clitemnestra. Realizado a quatro mãos o matricídio, Electra e Orestes estavam certamente aliviados e felizes por terem cumprido condignamente o desafio que lhes impôs o oráculo, embora o príncipe sempre o tivesse questionado (v. 967-81, 1190-1). Quase todos os seus desejos estavam realizados: a morte do pai estava finalmente vingada, e o trono argivo, liberto dos tiranos. Entretanto, alguma coisa acontecia - não tão fora do esperado, levando em consideração as reiteradas ponderações de Orestes sobre o matricídio: uma comoção tomou conta do cenário, que a princípio deveria ser de festa. Orestes, que sempre resistiu à ideia de matar a mãe, era o que, incomparavelmente, mais sofria: o herói chora e Electra se dá conta do quão excessivo foi o seu ódio (v. 1182-3). O coro, como noutros momentos, acompanhou os seus amigos: "Também eu choro por ela [Clitemnestra] que é subjugada pela mão dos filhos" (v. 1168).

Feito o paralelo entre a instituição da efebia e elementos correlatos (como os festivais das Apatúrias e das Oscofórias) com a efebia trágica, cabe-nos investigar se os efebos euripidianos, tendo executado passo a passo o ritual de iniciação, encontram-se, enfim, aptos a serem reintegrados à cidade, objetivo primordial da efebia. 
Cumpriu-se o oráculo apolíneo. Entretanto, o que parecia uma promessa para solução de todos os males ainda não havia chegado ao fim. Parte da audiência de Eurípides por certo aguardava os passos seguintes: ver Orestes perseguido pelas Erínias; na sequência, ser salvo pelo Conselho do Areópago em Atenas; finalmente, retornar feliz ao lar paterno, como lhes mostrara a clássica Orestéia de Ésquilo e como sugere a Electra sofocliana. Contudo, outra parte da audiência talvez suspeitasse que o poeta mais uma vez surpreenderia, mesmo no apagar das luzes. Eurípides conservou apenas a primeira parte do desfecho: o príncipe, perseguido pelas terríveis deusas, deverá seguir para a cidade de Palas e apresentar-se ao Conselho; submetendo-se a julgamento, será salvo, pois Lóxias assumirá a culpa (v. 1254ss). Quanto a ser reintegrado à pátria argiva e retomar a posse dos bens do pai no molde de Ésquilo (Eumênides, v. 754ss), o poeta optará por outra solução: os jovens serão banidos perpetuamente da pátria argiva, não é possível pisar nesse solo depois de matar a mãe (v. 1250), sentencia Castor.

Retrocedamos ao assassinato de Egisto. Como vimos, o clima era de tensão e expectativa na casa de Electra, enquanto ela e as amigas aguardavam o desfecho da parte do plano que cabia exclusivamente a Orestes. A chegada do mensageiro, entretanto, foi capaz não só de colocar um fim àquela angústia, mas de imprimir no cenário algo absolutamente novo, uma verdadeira reviravolta. O mensageiro mais se assemelhava àquele arauto esquiliano da tragédia Agamêmnon, antecipando o retorno de Agamenão após a sua vitória em Ílion e relatando os seus grandes feitos (Ésquilo, Agamêmnon, v. 503-537). As cenas subsequentes soam como uma espécie de compensação a Agamenão, restituindo-lhe, por assim dizer, as glórias, que ele não obteve em seu retorno.

Orestes agora é recepcionado com honras de chefe de estado: de exilado errante ascendeu a rei. Os servos são os primeiros a coroá-lo em clima festivo, quando o reconhecem ainda na cena do crime (v. 854). Na sequência, o coro, após ouvir do mensageiro o relato da vitória de Orestes sobre Egisto, afirma: “conquista o direito à coroa, teu irmão é o melhor/ daqueles junto aos rios de Alfeu,/ tendo cumprido sua tarefa" (v. 862-4). Nesse mesmo instante, Electra pede às amigas para trazer do interior da casa os ornamentos de cabelo para coroar o irmão (v. 870-2). Imediatamente ao chegar, Orestes é recebido efusivamente por Electra, cujo primeiro ato é a coroação do irmão. Ela depõe sobre seus cachos a coroa recém-confeccionada enquanto pronuncia um lisonjeiro discurso, elevando a vitória de Orestes ao nível dos feitos guerreiros alcançados por Agamenão (v. 880ss). Não por acaso, ao se dirigir ao pai no início da peça, ela lamenta: "Não com laços ornamentais tua mulher/ recebeu-te, nem com coroas,/ mas com punhal de duplo gume" (v. 162-4).

Electra, por seu turno, metamorfoseara-se, de triste cisne sonoro, que chorava à beira do lago, na monódia de lamento e súplica ao pai (v. 150ss), em uma corcinha alegre e saltitante para o céu, como o coro pede para que ela se assemelhe ante a notícia do triunfo alcançado por Orestes frente a Egisto (v. 860-1). Desse modo, acendem-se as luzes da fronteira para a grande festa: a choupana lúgubre de Electra transforma-se momentaneamente em palácio real, onde assistimos à entronização do novo rei e o entusiasmo da jovem com 
direito a dança ${ }^{10}$ e canto (v. 874-5). Nessa casa, transmudada em palácio real, assistimos ao "julgamento" de Egisto, condenado a perder o seu posto de senhor da cidade e, em vertiginosa derrocada, descer à posição de escravo (v. 899); é nessa condição que Orestes presenteia seu cadáver à irmã.

O príncipe Atrida tinha consciência de que o matricídio redundaria no exílio (v. 975). Eurípides o pôs a par das leis da cidade do século V a.C., que estabeleciam tal pena. Segundo Arnaoutoglou (2003, p. 82), em Nomina I, 02 (= IGI3 104), uma inscrição de 409408 a.C., lê-se na primeira coluna: "Mesmo que uma pessoa mate sem intenção, será exilada". Orestes chegou a levantar essa questão junto a Electra antes do crime (v. 961ss), contudo, a jovem, obstinada, é implacável, atingindo-o sobremaneira em sua honra masculina: “Que não caias na falta de virilidade acovardando-te/ mas vai colocar-te à espreita com a mesma armadilha para ela/ com a qual abateste o esposo Egisto, matando-o" (v. 982-4). Diante de tão mordaz apelação, não cabia a Orestes, o jovem efebo, que tentava a todo custo subir ao reino dos homens adultos guerreiros, senão provar que finalmente estava pronto: "Entrarei. Inicio uma terrível marcha/ e farei mesmo um ato terrível. Se isto parece bem aos deuses,/ que seja. Amarga, e não doce, será a luta para mim" (v. 985-7).

O cadáver da mãe estendido, ensanguentado, o peito aberto, Orestes, que chora, é tomado de desespero, enquanto Electra se dá conta do quão excessivo fora seu ódio (v. 1182-3). O ambiente experimenta o vazio e a tristeza, bem diferente daquele palácio em festa ao exibir o troféu/cadáver, como vimos.

Nesse instante, Eurípides põe em cena a epifania dos Dióscuros, ex machina. Castor, o antigo pretendente de Electra (v. 310), reprova o ato de Orestes, conquanto considere justa a morte de Clitemnestra (v. 1243). Apolo é culpabilizado pelo matricídio (v. 1244, 1246, 1297 , 1302), portanto, os irmãos não portam a mácula da polução. Talvez o que se segue seja, para eles, mais doloroso do que seria a própria polução. Eis a sentença divina:

I) Para Orestes: 'e tu deixa Argos, pois não é possível que pises/ nesta cidade [pólis] depois de matar tua mãe” (v. 1250-1) (...) É preciso que tu vivas em uma cidade [pólis] da Arcádia/ junto às correntezas de Alfeu, perto do Santuário do Liceu./ E a cidade [pólis] será chamada pelo teu nome' (v. 1273-5).

II) Para Electra: 'Que Pílades, então, com sua esposa virgem,/ saia da terra aquéia e vá para a sua casa [na Fócia],/ que ele leve consigo o teu cunhado de nome [o camponês]/ para as terras dos fócios e lhe dê ampla riqueza' (v. 1284-7).

Quando Orestes lamenta ter tão tardiamente se reaproximado da irmã e no instante seguinte ter forçosamente de se afastar, Castor lhe diz: "Ela tem um esposo e uma casa, não/ há o que se lamentar, exceto que/ está abandonando a cidade [pólis] de Argos” (v. 1311-3).

\footnotetext{
${ }^{10}$ Para Moreau (1992, p. 208), a dança pode ser um sinal do rito iniciático e aparecer no curso da prova ou com uma função simbólica.
} 
Mas o que soava como uma simples exceção para a Divindade era o que de maior e mais sagrado os irmãos poderiam perder. É Electra quem afirma: "E que outros gemidos são maiores/ que deixar as fronteiras [hóroi] da terra pátria [gês patrías]?” (v. 1314-5). E Orestes, que por anos havia amargado o exílio, desabafa: "E eu que me retiro da casa do pai/ e a votos alheios submeterei/ o assassinato de minha mãe" (v. 1316-8).

O ritual da efebia tem por irrestrita finalidade incorporar o jovem ao seu oîkos. Eurípides que, abandonando o aspecto religioso do crime, a polução, opta por fazer valer o aparato jurídico da pena para o matricídio, o exílio, lança uma nova fórmula de (re)integração, atípica, sem dúvida, posto que os jovens serão integrados, sem nenhuma exclusão, em outras cidades.

Ouvimos da Divindade a promessa de que Orestes não só será homenageado e reconhecido, emprestando o seu nome a uma cidade da Arcádia, como será feliz quando terminar a sua missão (v. 1290-1). Por um lado, nomear a cidade implica o reconhecimento a Orestes, um distintivo, e a sua incondicional integração a um novo ô̂kos; por outro, restabelece a identidade do jovem como filho de Agamenão - guerreiro e patriota à semelhança do pai. Electra, por seu turno, livrar-se-á da sua grande preocupação: ela terá um lugar que a acolherá, um coro e um casamento (v. 1198-200).

Nesses termos, podemos concluir que a efebia trágica estava completada de um modo suigeneris. A fronteira argiva, que recebeu a princesa, expulsa do palácio como castigo, apresentou-se como libertadora a desagrilhoar a jovem, transformando-a na mais libertária das Electras. O jovem Orestes, sem poder alcançar a ásty ("cidade"), encontra no espaço rural todos os meios para levar a cabo os planos de justiça/vingança. Juntos, na khóra argiva, os efebos, auxiliados pelo corpo técnico, realizam suas tarefas; são, desse modo, integrados aos novos ổkoi e têm suas identidades restabelecidas. Posto dessa forma, no nível do texto poético, podemos assistir a um ritual de efebia trágica, proporcionado pela capacidade inventiva e intelectual de Eurípides em sua Electra.

\section{REFERÊNCIAS}

APOLODORO. Contra Neera [Demóstenes], 59. Tradução Glória Onelley. Introdução e notas Ana Lúcia Curado. São Paulo: Annablume Clássica; Coimbra: IUC, 2012.

ARISTÓTELES. Poética. Tradução Eudoro de Souza. São Paulo: Ars Poetica, 1993.

ARISTÓTELES. A Constituição de Atenas. Tradução e comentários Francisco Murari Pires. Ed. bilíngue. São Paulo: Hucitec, 1995.

ARNAOUTOGLOU, Ilias. Leis da Grécia Antiga. Trad. Ordep Serra e Rosiléa Carnelós. São Paulo: Odysseus, 2003.

BIGNO'TTO, N. O tirano e a cidade. São Paulo: Discurso Ed., 1998.

CAREY, C. Legal space in classical Athens. Greece \& Rome, Second Series, v. 41, p. 172-86, 1994. Disponível em: <http://www.jstor.org/stable/643012>. Acesso em: 20 maio 2013. 
CHEVITARESE, A. L. O espaço rural da pólis grega: o caso ateniense no Período Clássico. Rio de Janeiro: Fábrica de Livros/SENAI/RJ, 2000.

ÉSQUILO. Coéforas/Ésquilo (Oresteia II). Estudo, tradução Jaa Torrano. São Paulo: Iluminuras FAPESP, 2004.

ÉSQUILO. Agamêmnon/Ésquilo. Estudo, tradução Jaa Torrano. São Paulo: Iluminuras FAPESP, 2004.

ÉSQUILO. Eumênides/Ésquilo. Estudo, tradução Jaa Torrano. São Paulo: Iluminuras FAPESP, 2004.

EURÍPIDES. Electra de Eurípides: estudo e tradução. Tradução Karen Amaral Sacconi. 2012. Dissertação (Mestrado) - USP, São Paulo, 2012. Disponível em: < http:/ /www.teses.usp.br/ teses/disponiveis/8/8143/tde-30102012-115821/pt-br.php>. Acesso em: ago. 2012.

FLORENZANO, M. B. B. Nascer, viver e morrer na Grécia antiga. São Paulo: Atual, 1996.

GASTI, Eleni. L'Oreste sofocleo e l'efebia. La Parola Del Passato. Rivista di studi antichi, Napoli: Gaetano Macchiaroli, v. CCCXX, 2001, p. 313-27. Disponível em: < http://www.academia. edu/1533930/LOreste_sofocleo_e_lefebia>. Acesso em: 03 jul. 2014.

GIANGIULIO, M. L'eschatia prospective critiche su reppresentazione Antiche e Modelli moderni. In: Problemi della Chora Coloniale dall'Occidente al Mar Nero. Atti del Convegno di studi sulla Magna Grecia 40, 2000; Taranto, 2001, p. 333-61.

HOMERO. Odisseia. Tradução Frederico Lourenço. Lisboa: Biblioteca Editores Independentes, 2010.

ISLER-KERÉNYE, C. Dyonisos in Archaic Greece: an understanding through images. Translated by Wilfred G.E. Watson. Leiden: Brill, 2007.

KUBO, M. The norm of myth: Euripides' Electra. Harvard Studies in Classical Philology, v. 71, p. 15-31, 1967. Disponível em: <www.jstor.org/stable/310753>.

MOREAU, Alain. Initiation en Grèce antique. Dialogues d'histoire ancienne, v. 18, n.1, p. 191244, 1992.

ORTH, F. "Jagd": s.v. "Jagd”, Real-Encyclopädie der classischen Altertumswissenschaft, v.9, p. 558604, 1914.

PLUTARCO. Vidas Paralelas. I. Teseo - Rómulo, Licurgo - Numa. Tradução Aurélio Pérez Jiménez. Madrid: Gredos, 1985.

POLINSKAYA, Irene. Liminality as metaphor: initiation and frontiers of Ancient Athens. In: DODD, David B.; CHRISTOPHER, A. Faraone (ed.). Initiation in Ancient Greek Rituals and Narratives. London; New York: Routledge, 2003. 
PSEUDO-XENOFONTE. A constituição dos Atenienses. Tradução Neyde Theml e André Leonardo Chevitarese. In: COSTA, Ricardo da (org.). Testemunhos da História. Documentos de História Antiga e Medieval. Vitória: Edufes, 2002.

RONNET, G. L'ironie d'Euripide dans l'Électre (vers 513 a 546). Revue des Études Grecques, v. LXXXVIII, p. 419-23, 1975.

SIEWERT, P. The Ephebic Oath in Fifth-century Athens. JHS 97, 1977, p. 102-11. Disponível em: <www.jstor.org/stable/631025>. Acesso em: 10 jun. 2013.

SÓFOCLES. Electra. Sófocles/Eurípides. Electra(s). Tradução Trajano Vieira. São Paulo: Ateliê, 2009.

SÓFOCLES. Édipo rei, Édipo em Colono, Antígona. Tradução Mário da Gama Kury. São Paulo: Jorge Zahar, 2001.

VICKERS, B. Towards Greek Tragedy. London: Longmans, 1973.

VIDAL-NAQUET, P. Le chasseur noir. Formes de pensée et formes de société dans le monde grec. Paris: La Découverte; Maspero, 1983.

VIDAL-NAQUET, P. A caça e o sacrifício na "Oréstia” de Ésquilo. In: VERNANT, J.-P.; VIDAL-NAQUET, P. Mito e tragédia na Grécia antiga. São Paulo: Brasiliense, 1988, p. 101-24.

VIDAL-NAQUET, P. O “Filoctetes” de Sófocles e a efebia. In: VERNANT, J.-P.; VIDALNAQUET, P. Mito e tragédia na Grécia antiga. São Paulo: Brasiliense, 1988, p. 125-145.

VIDAL-NAQUET, P. Retour au chasseur noir. In: VERNANT, J.-P. e VIDAL-NAQUET, P. La Grèce ancienne. Rites de passages et transgressions. Paris: Le Seuil, 1992, p. 215-251.

XENOPHON. Hellenica. Vol.I. Trans. C. L. Brownson. The Loeb Classical Library. Cambridge Mass.: Harvard University Press, 1918.

WINKLER, J. J. The Ephebes' song. Playing the Other: Theather, Theatricality, and the Feminine in Greek Drama. In: WINKLER, J., ZEITLIN, F. (org.). Nothing to do with Dionysos? Athenian Drama in Its social context. Princeton: Princeton University Press, 1992, p. 20-62.

ZACHARIA, K. Converging Truths. Euripides' Ion and the Athenian Quest for Self-Definition. Boston: Brill, 2003.

ZEITLIN, Froma. The Argive Festival of Hera and Euripides' Electra. In: MOSSMAN, Judith (ed). Oxford Readings in Classical Studies: Euripides. Oxford: Oxford University Press: 2003, p. 261-84.

ZEITLIN, Froma. The Argive Festival of Hera and Euripides' Electra. American Philological Association, v. 101, p. 645-69, 1970. Disponível em: < http://www.jstor.org/stable/2936074>. Acesso em: 16 nov. 2012.

Recebido em: 11 de abril de 2016 Aprovado em: 19 de julho de 2016 